\title{
Identifikasi dan Klasifikasi Sinyal EEG terhadap Rangsangan Suara dengan Ekstraksi Wavelet dan Spektral Daya
}

\author{
Esmeralda C. Djamal ${ }^{1} \&$ Harijono A. Tjokronegoro ${ }^{2}$ \\ ${ }^{1}$ Mahasiswa Program S3 Departemen Teknik Fisika ITB, \\ email: alda@students.tf.itb.ac.id \\ ${ }^{2}$ Departemen Teknik Fisika ITB, email: hanegoro@indo.net.id
}

\begin{abstract}
Abstrak. Pada penelitian ini telah dibangun sistem identifikasi dan klasifikasi tiga komponen gelombang di dalam sinyal EEG, yaitu gelombang alpha, beta dan teta. Teknik identifikasi dan klasifikasi yang dimaksud adalah kombinasi dari transformasi wavelet dan analisis spektral daya. Transformasi wavelet dimaksudkan untuk ekstraksi gelombang EEG serta mereduksi data tanpa kehilangan informasi. Transformasi wavelet juga dapat menurunkan aspek nonstasioner sinyal EEG. Sistem klasifikasi selanjutnya dilakukan berdasarkan tingkat kemunculan gelombang EEG, keseimbangan kanal simetrik, dan dominasi spektral daya pada daerah frekuensi gelombang masing-masing. Sinyal EEG yang digunakan dalam penelitian ini diperoleh dari 5 nara coba, yang kepada masing-masing diberi rangsangan suara selama 2.5 menit. Terdapat 10 jenis musik dan 2 jenis suara alami digunakan sebagai rangsangan suara dalam penelitian. Selanjutnya untuk setiap rangsangan suara yang diberikan, 16 kanal sinyal EEG dianalisis. Hasil penelitian ini menunjukan rangsangan suara dapat menyebabkan peningkatan kemunculan gelombang alfa dengan $75 \%$, sedangkan gelombang teta dan beta menurun sekitar $48 \%$ dan $56 \%$. Sementara itu, rangsangan suara yang diberikan mengakibatkan pula peningkatan keseimbangan kanal simetrik untuk ketiga gelombang EEG menjadi sekitar 75\%. Hasil penelitian menunjukan pula bahwa ekstraksi sinyal dengan wavelet packet memberikan penyimpangan yang lebih kecil, dan meminimalkan pengaruh nonstasioner, sehingga memperbaiki analisis spektral daya yang dpergunakan.
\end{abstract}

Kata kunci: ekstraksi wavelet; spektral daya; deteksi dan identifikasi sinyal EEG; rangsangan suara.

\begin{abstract}
In this research the development of identification and classification technique of three wave components of EEG signal, named alpha, beta and theta, is considered. The technique is combination of wavelet transform and power spectral analysis. Wavelet transform was used to extract the wave components so it reduces the data without loss of the information. The wavelet transform also reduces the aspects of non-stationary of the EEG signal. The EEG's wave classification was based on the appearance of the wave, synchronization between symmetric hemispheres, and the wave energy
\end{abstract}

Makalah diterima redaksi tanggal 9 Desember 2004, revisi diterima tanggal 27 Mei 2005, diterbitkan tanggal 19 Juni 2005. 
dominance, in its frequency region. The EEG signals used in this research were obtained from 5 individually-independent subjects after 2.5 minutes sound stimulation. 10 sounds of music and 2 natural sounds were used as sound stimulation in this research. Then, 16 channels of EEG signals, obtained from every individual subject after a sound stimulation, were analyzed. The technique shows that the sound stimulation increases the appearance of the alpha wave by $75 \%$ and decreases beta and theta waves by $48 \%$ and $56 \%$, respectively. Furthermore, the sound stimulations were used in the research to increase the synchronization balance between symmetric channels by $75 \%$. In addition, this research shows that the signal extraction using wavelet packet provided small deviation and reduced non-stationary aspects, so that it improves the power spectral analysis used in the technique.

Keywords: wavelet extraction; power spectral; detection and identification of EEG signal; sound stimulation.

\section{Pendahuluan}

Elektroensephalogram (EEG) adalah instrumen untuk menangkap aktifitas listrik di otak. Kalangan kedokteran menggunakan EEG antara lain untuk diagnosa penyakit yang berhubungan dengan kelainan otak dan kejiwaan. Sementara aplikasi lebih luas dari EEG adalah untuk mendeteksi pola pikiran atau kondisi mental seseorang. Pengamatan visual terhadap sinyal EEG secara langsung sangat sukar mengingat amplitudo sinyal EEG demikian rendah dan polanya yang sangat kompleks. Disamping itu sinyal EEG amat dipengaruhi oleh berbagai variabel, antara lain kondisi mental, kesehatan, aktivitas dari pasien, lingkungan perekaman, gangguan listrik dari organ tubuh lain, rangsangan luar, dan usia dari pasien. Sifat sinyal EEG pada umumnya adalah non-stasioner dan random sehingga menambah kompleksitas dalam pengolahan sinyal EEG. Namun demikian, klasifikasi dari sinyal EEG terhadap perubahan variabel tertentu dapat menerangkan fungsi kerja dari otak dan menangkap perubahan aktifitas otak terhadap variabel yang bersangkutan.

Transformasi sinyal EEG menjadi suatu model, merupakan suatu cara yang efektif dalam analisis untuk tujuan klasifikasi sinyal EEG. Sinyal EEG pada seseorang, umumnya terdiri dari komponen-komponen gelombang yang dibedakan berdasarkan daerah frekuensinya, yaitu gelombang alfa $(8-13 \mathrm{~Hz})$, amat sering muncul dalam keadaan sadar, mata tertutup dan kondisi rileks; gelombang beta $(14-30 \mathrm{~Hz})$, amat sering muncul manakala seseorang dalam keadaan berfikir; gelombang teta $(4-7 \mathrm{~Hz})$, umumnya terjadi pada seseorang yang sedang tidur ringan, mengantuk atau stres emosional; gelombang delta $(0.5-3 \mathrm{~Hz})$, amat sering hadir pada seseorang yang pada keadaan tidur nyenyak. Oleh karena itu, representasi sinyal EEG ke dalam domain frekuensi banyak dilakukan dalam penelitian yang berhubungan dengan analisis sinyal 
EEG. Representasi dalam domain frekuensi antara lain untuk mencari kemunculan gelombang tertentu terhadap rangsangan suara ${ }^{[16]}$, analisis pengaruh frekuensi kedipan cahaya ${ }^{[15]}$, dan model untuk klasifikasi sinyal EEG terhadap empat kondisi pikiran ${ }^{[3]}$, serta identifikasi gelombang pada sinyal $\mathrm{EEG}^{[7]}$. Namun representasi sinyal EEG ke dalam domain frekuensi yang biasanya menggunakan transformasi Fourier, resolusinya dibatasi oleh jumlah data yang tersedia. Teknik transformasi Fourier secara langsung juga kurang sesuai untuk sinyal non-stasioner seperti sinyal EEG. Kedua hal tersebut merupakan kendala sangat penting pada aplikasi transformasi Fourier secara langsung untuk anaisis sinyal EEG yang non-stasioner, disamping kondisikondisi yang ingin diperhatian sering kejadiannya pada waktu yang sangat singkat. Salah satu alternatif untuk mengatasi kelemahan di atas, adalah dengan menggunakan transformasi wavelet sebagai pra-pengolahan sinyal. Transformasi wavelet dapat mengekstraksi komponen-komponen sinyal hanya pada frekuensi yang diperlukan sehingga dapat mereduksi pula jumlah data namun tanpa kehilangan informasi yang berarti. Selain itu metoda ini sesuai untuk sinyal non-stasioner. Keluaran dari transformasi wavelet dalam domain waktu, memungkinkan penggunaannya sebagai pra model, sebelum kemudian diproses ke dalam domain frekuensi. Penelitian sinyal EEG yang menggunakan transformasi wavelet antara lain untuk klasifikasi rangsangan visual ${ }^{[16]}$, klasifikasi sinyal EEG dengan dua kondisi pikiran dengan pengenalan hingga $83 \%{ }^{[10,11]}$, identifikasi gelombang epilepsi ${ }^{[22]}$, serta untuk mengenali gerakan $\operatorname{artifak}^{[14]}$. Transformasi wavelet juga dapat digunakan sebagai model pada kasus sinyal EEG epilepsi dengan pengenalan sekitar $80 \%$ yang lebih baik dari model parametrik [19], serta sebagai model untuk tahapan tidur dengan keberhasilan $70-80 \%^{[17]}$.

\subsection{Suara Untuk Merangsang Kehadiran Gelombang EEG}

Rangsangan suara merupakan salah satu variabel yang dapat mempengaruhi kehadiran gelombang listrik di otak. Oleh karena itu, untuk keperluan terapi emosional dan kejiwaan sering digunakan rangsangan suara untuk dicapainya peningkatan gelombang tertentu pada otak. Meskipun persepsi seseorang terhadap suara yang diterima berbeda-beda, namun secara umum suatu rangsangan suara akan membentuk pola tertentu pada sinyal EEG yang diberikannya. Ini berarti pula bahwa rangsangan suara dapat menyebabkan seseorang berada pada kondisi pikiran dan emosi tertentu, misalnya kondisi rileks ${ }^{[26,19]}$. Penelitian tersebut telah mengidentifikasi kondisi rileks dari peningkatan gelombang alfa dan makin seimbangnya gelombang-gelombang listrik yang berasal dari daerah/kanal otak kiri dan kanan. Demikian pula penelitian yang dilakukan oleh Oohashi (1991), menggunakan suatu jenis musik yang kaya frekuensi tinggi ( $>20 \mathrm{kHz}$ ), terhadap 16 mahasiswa sebagai naracoba, dimana sekitar $80 \%$ diantaranya dapat memberikan peningkatan 
gelombang alfa. Lebih jauh, pada musik klasik dan sebagian musik berirama lembut dapat memberikan kondisi rileks seseorang. Demikian pula penggunaan suara alami seperti suara air dan suara kicauan burung dapat pula menyebabkan kondisi rileks ${ }^{[19,23]}$.

\subsection{Sistem Deteksi dan Identifikasi Gelombang EEG}

Pada penelitian ini telah dibangun sistem deteksi dan identifikasi gelombanggelombang di otak terhadap rangsangan suara dengan menggunakan teknik pengolahan sinyal kombinasi transformasi wavelet dan spektral daya. Dalam penelitian ini pengaruh variabel lain (selain rangsangan suara yang diberikan) diminimalkan. Analisis dilakukan melalui teknik deteksi dan identifikasi gelombang-gelombang otak yang dibangun menggunakan ekstraksi wavelet dan analisis spektral daya. Transformasi dan analisis wavelet dilakukan untuk proses ekstraksi komponen-komponen gelombang alfa, beta, dan teta dari sinyal EEG. Selanjutnya pengamatan spektral daya dilakukan terhadap daerah frekuensi masing-masing gelombang tersebut guna mengidentifikasi tingkat kehadiran dari masing-masing gelombang. Penelitian ini merupakan pengembangan penelitian yang lalu ${ }^{[11-12]}$, dengan melakukan pengembangan rangsangan suara yang bervariasi. Sehingga disamping sistem klasifikasi, juga dimaksudkan untuk memperoleh informasi jenis/ karakteristik beberapa rangsangan suara yang dapat membangkitkan gelombang tertentu pada otak.

\section{Deskripsi Sinyal EEG}

Set-up sistem pengukuran sinyal EEG biasanya menggunakan metoda International Federation of Societes of Electroencephalography, dimana elektroda ditempatkan pada kulit kepala pada posisi/aturan standar yaitu sistem 10 - 20, sebagaimana ditunjukan pada Gambar 1. Sementara itu berdasarkan aktifitas listrik pada otak, dibedakan atas set titik ukur: Frontal (F), untuk pengontrolan, kemampuan bicara, perencanaan gerakan dan pengenalan; Parietal (P), untuk menerima informasi rangsangan sentuhan, temperatur, posisi tubuh dan vibrasi; Occipital (O), untuk menerima rangsangan visual dan arti tulisan; dan Temporal (T), untuk menerima informasi rangsangan dari telinga dan berkaitan dengan memori.

Data sinyal EEG untuk penelitian ini diambil dengan menggunakan instrumen Sigma PL Pro yang ada di RS Jiwa Bandung. Mengingat keterbatasan pada alat ukur tersebut, analisis pada penelitian ini hanya menggunakan 16 kanal (Gambar 1). Hal ini tidak menjadi kekurangan pada analisis karena sinyal EEG yang menjadi perhatian adalah terhadap rangsangan suara yang terkonsentrasi pada ke-16 kanal tersebut. Dalam hal ini, yang berperan banyak adalah sinyal EEG dari informasi sekitar temporal. 


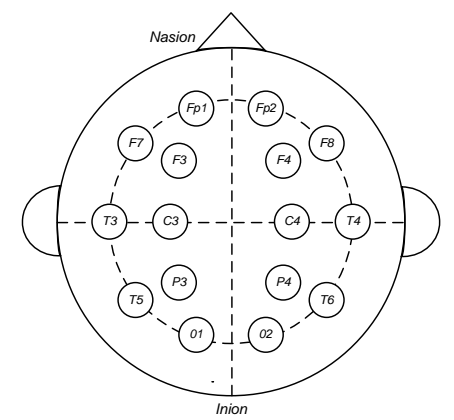

Gambar 1 Penempatan sensor EEG berdasarkan sistem 10-20 untuk 16 kanal pada eksperimen.

Pada penelitian ini, dilakukan pengukuran terhadap 5 naracoba, mahasiswa usia 20-30 tahun, yang sehat jasmani serta menyatakan dirinya tidak mempunyai tekanan psikologis apapun, dan dengan sukarela menjadi naracoba dalam penelitian ini. Penetapan jumlah naracoba pada penelitian ini semata-mata didasarkan pada ketersediaan naracoba yang tersedia, sukarela dan yang memenuhi persyaratan kesehatan, disamping mengacu pula jumlah naracoba yang digunakan pada sejumlah penelitian terdahulu ${ }^{[1,2,3,13,14,19,20,22]}$. Pada perekaman data sinyal EEG, nara coba duduk rileks, berada di dalam ruang yang tenang dan bebas dari bising serta diusahakan dalam keadaaan nyaman. Perekaman demikian dimaksudkan agar dapat meminimalkan pengaruh variabel lain yang dapat berpengaruh pada kehadiran sinyal EEG.

Rangsangan suara diberikan kepada naracoba melalui headphone, dengan kekerasan suara yang diusahakan sesuai dengan kenyaman naracoba. Setiap sumber suara diberikan selama dua menit, dengan didahului oleh kondisi diam (tanpa rangsangan suara) selama setengah menit. Untuk meminimalkan pengaruh urutan sumber suara, setiap perulangan menggunakan urutan yang berbeda. Hal ini berkaitan, dengan penelitian terdahulu bahwa sumber suara yang berada di akhir waktu cenderung menyebabkan naracoba mengantuk ${ }^{[5,6,7]}$. Terhadap masing-msing naracoba dilakukan pengukuran sebanyak 4 kali. Sumber suara yang digunakan dalam penelitian ini sebanyak 12 (duabelas) suara, terdiri dari 6 musik klasik dari Mozart dan Beethoven, 4 musik instrumental David Foster, serta 2 suara alami (suara burung dan suara air terjun). Terhadap 12 rangsangan suara tersebut, diidentifikasi instrumen musik yang dominan yang dimainkan, yang meliputi warna musik, jenis musik, dan temponya. Untuk ini telah dilakukan konsultasi dengan 2 orang pakar musik [23,24]. Adapun analisis karakteristik rangsangan suara tersebut diperlihatkan pada Tabel 1 . 
Table 1 Sumber suara dari data eksperimen.

\begin{tabular}{|c|c|c|c|c|c|}
\hline No & Judul Suara & $\begin{array}{l}\text { Instrumen } \\
\text { Dominan }\end{array}$ & Warna & Jenis & $\begin{array}{c}\text { Tempo } \\
\text { (per menit) }\end{array}$ \\
\hline 1 & Fuer Elise & Biola, cello,bass & minor & Lunak & $75-80$ \\
\hline 2. & Allegretto & Piano & mayor & Tajam & 90 \\
\hline 3. & Adagio & Piano & minor & agak tajam & $50-55$ \\
\hline 4. & Minuet & Biola, cello,bas & minor & agak lunak & 60 \\
\hline 5. & Andante & Piano & mayor & agak lunak & $60-65$ \\
\hline 6. & $\begin{array}{l}\text { Moonlight } \\
\text { Sonata }\end{array}$ & Piano & minor & lunak, datar & 50 \\
\hline 7. & St Elmo's Fire & Piano, biola,cello & minor & agak lunak & $80-90$ \\
\hline 8. & Water Fountain & Piano & minor & $\begin{array}{l}\text { agak lunak, } \\
\text { sedikit tajam }\end{array}$ & 90 \\
\hline 9. & Winter Games & Keyboard, flute & mayor & Tajam & 70 \\
\hline 10. & The Color Purple & Piano,keyboard & minor & agak lunak & 60 \\
\hline 11 & Suara Air Terjun & Air terjun alami & minor & $\begin{array}{c}\text { sangat } \\
\text { lunak, datar }\end{array}$ & 50 \\
\hline 12 & $\begin{array}{c}\text { Suara Burung } \\
\text { di hutan }\end{array}$ & Suara burung & mayor & agak tajam & 65 \\
\hline
\end{tabular}

Penggunaan suara tersebut diduga secara apriori dapat memberikan kondisi tenang/ rileks seperti yang diketahui dari penelitian terdahulu ${ }^{[19,23]}$. Sumber suara yang digunakan kemudian dievaluasi pengaruhnya terhadap kemunculan gelombang tertentu pada EEG, dan juga kondisi emosional dari seseorang.

\subsection{Digitasi Sinyal EEG dari Citra EEG pada Layar Monitor}

Pemrosesan sinyal EEG dilakukan terhadap keluaran dari Sigma PL pro melalui tahapan digitasi yang dilukiskan pada Gambar 2.

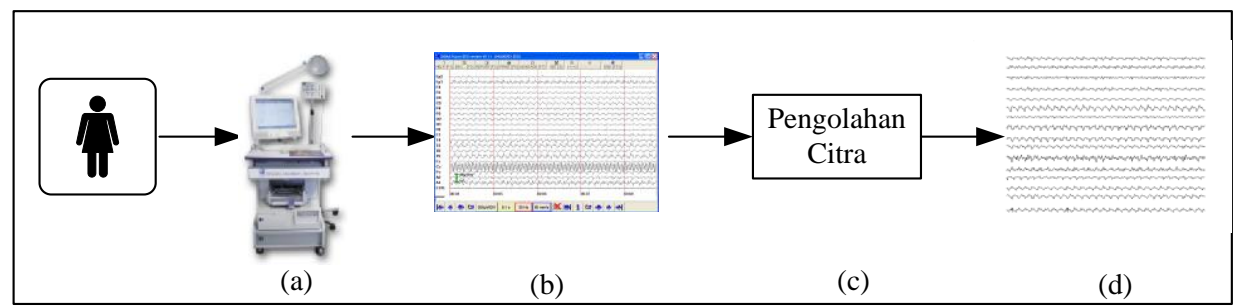

Gambar 2 Akuisisi data dan pengolahan citra digital.

Pada tahap pertama dilakukan perekaman sinyal EEG menggunakan instrumen Sigma PL pro (Gambar 2a), sehingga menghasilkan keluaran sinyal EEG pada layar monitor (Gambar 2b). Dalam penelitian ini, tiap layar monitor 
menampilkan sekaligus 22 kanal sinyal EEG dengan durasi 4 detik. Seperti yang telah disebutkan di depan, pada kenyataannya instrumen Sigma PL Pro tidak dapat memberikan sinyal EEG digital yang dapat langsung diproses, melainkan dalam bentuk gambar grafik pada layar monitor. Oleh karena itu, perlu dilakukan konversi (Gambar 2.c) untuk mendapatkan sinyal EEG digital ekivalen (Gambar 2d). Konversi data digital dilakukan dengan menggunakan fungsi "imread.m" yang tersedia pada perangkat lunak Matlab. Fungsi tersebut dapat mengidentifikasi warna pada setiap titik (píxel) dari gambar sinyal EEG (dengan format bmp). Dengan pengembangan serta modifikasi pada fungsi tersebut, dapat diketahui posisi (koordinat) vertikal dari setiap titik (píxel) hitam pada citra grafik pada setiap posisi horisontal (sumbu waktu). Dalam hal ditemukan lebih dari satu titik hitam pada statu garis vertikal, maka dipilih titik hitam yang berada di posisi di tengah. Dengan cara demikian dapat diperoleh data digital (time series) dari sinyal EEG yang bersangkutan. Pada proses digitasi di atas, sumbu horisontal menjadi sumbu waktu, sementara sumbu vertikal menjadi amplitudo sinyal EEG. Untuk memberikan hasil digitasi yang baik, setiap citra yang ditangkap direkam dengan format hitam putih yang kontras. Untuk validasi sebelum pemrosesan, sinyal EEG yang diperoleh (Gambar 2.d) dibandingkan terlebih dahulu dengan grafik EEG asli (Gambar 2.b). Contoh hasil digitasi terhadap sinyal dari grafik ditunjukkan pada Gambar 3. Pada gambar tersebut ditunjukan contoh untuk 3 potongan sinyal EEG (a), (b), dan (c), masing-masing sebelah atas adalah sinyal gambar pada layar monitor, dan sebelah bawah adalah hasil digitasi yang diperoleh.

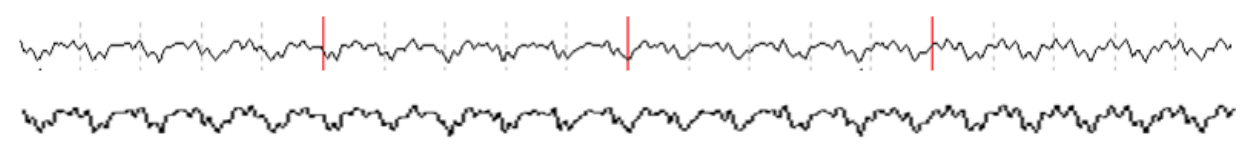

(a) Naracoba 1 Kanal Fp2
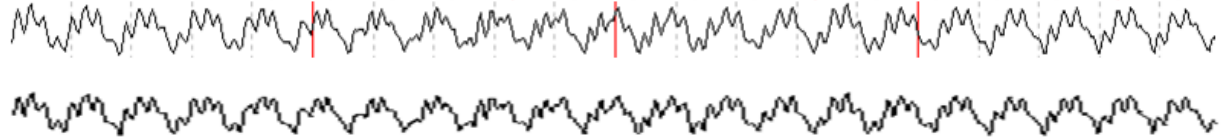

(b) Naracoba 1 Kanal Fp2

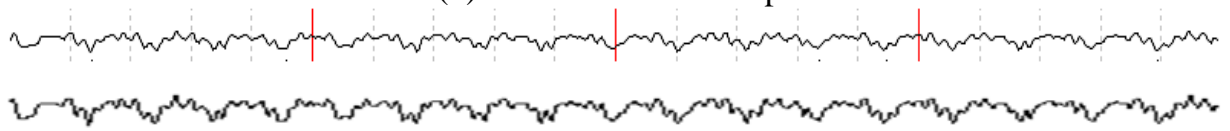

(c) Naracoba 2 Kanal Fp2

Gambar 3 Perbandingan antara grafik sinyal EEG asli (atas) dan hasil digitasi (bawah).

Terlihat pada Gambar 3 bahwa antara grafik sinyal EEG asli dan hasil digitasi memberikan kesesuaian yang cukup baik. Dengan ukuran gambar yang 
ditangkap layar, untuk setiap kanal terdiri dari 790 (horizontal) x 570 (vertikal) titik, selama 4 detik, sehingga data digital sinyal EEG yang diperoleh adalah ekivalen dengan frekuensi sampling 790 titik/4 detik $=197,5$ titik/detik.

\subsection{Langkah-langkah Pengolahan Sinyal EEG}

Dari setiap sinyal EEG digital yang diperoleh di akhir konversi, digabungkan sehingga sinyal EEG dari setiap sumber suara memiliki panjang 150 detik (30 detik tanpa suara dan 120 detik dengan suara). Untuk pemrosesan, selanjutnya sinyal EEG tersebut dibagi atas interval sepanjang 10 detik. Waktu 10 detik diambil dengan pertimbangan agar diperoleh cukup banyak data untuk analisis, tetapi masih cukup pendek agar sinyal EEG masih dapat mendekati sifat stasioner. Selanjutnya pemrosesan dilakukan, dengan 4 tahap. Tahap pertama, dilakukan pra-proses meliputi normalisasi dan sentralisasi (centering). Normalisasi di daerah gelombang digunakan untuk meminimalnya pengaruh amplitudo dari tiap daerah gelombang, karena fokus penelitian adalah kemunculan gelombang-gelombang di otak. Sementara sentralisasi dimaksudkan untuk menghilangkan komponen sinyal DC; Tahap kedua, dilakukan dekomposisi sinyal (transformasi wavelet) berdasarkan wavelet packets 5 langkah dengan fungsi basis symmlet 7 . Penentuan fungsi basis ini dengan pertimbangan mewakili bentuk sinyal EEG yang tak simetrik, dan kesesuaian dengan sinyal asli. Di dalam langkah dekomposisi ini dilakukan ekstraksi komponen gelombang EEG yang diperhatikan. Dalam hal ini adalah gelombang alfa, beta, dan teta. Adapun uraian dekomposisi ini akan diberikan pada Bagian 3. Tahap ketiga, analisis spektral daya dilakukan dengan metoda Welch dan window Bartlett terhadap sinyal EEG yang telah terekstraksi pada tahap sebelumnya. Keempat, identifikasi dan deteksi gelombang-gelombang EEG, merupakan tahap akhir proses pengolahan sinyal EEG yang akan dijelaskan lebih lanjut pada Bagian 5.

\section{Transformasi Wavelet}

Transformasi wavelet diskrit terhadap sinyal $x(n)$ diberikan oleh sepasang persamaan analisis:

$$
C(\sigma, \tau)=\sum_{n} x(n) \psi_{\sigma, \tau}^{*}(n)
$$

dan sintesis:

$$
\hat{x}(n)=\sum_{\sigma} \sum_{\tau} C(\sigma, \tau) \psi_{\sigma, \tau}(n)
$$

dimana 


$$
\psi_{\sigma, \tau}(n)=\frac{1}{\sqrt{|\sigma|}} \psi\left(\frac{n-\tau}{\sigma}\right)
$$

adalah fungsi basis wavelet, dengan $\sigma$ dan $\tau$ berturut-turut adalah faktor skala dan pergeseran. Jika kedua faktor tersebut diambil sebagai $\sigma=2^{j}$ dan $\tau=2^{j} k$, dimana $k, j \in \mathrm{I}$, maka analisis wavelet pada domain frekuensi terjadi pada sekuens oktaf demi oktaf terhadap fungsi basis (fungsi wavelet):

$$
\psi_{j, n}(n)=2^{j / 2} \psi\left(2^{j} n-k\right)
$$

Dengan faktor skala yang berubah secara dyadic di atas, maka sintesis (3) dapat difaktorisasi atas dua kelompok skala yang ekivalen dengan rentang frekuensi rendah dan frekuensi tinggi dari sinyal:

$$
\hat{x}(n)=\sum_{k} c(j, k) \varphi_{j, k}(n)+\sum_{j} \sum_{k} d(j, k) \psi_{j, k}(n)
$$

Suku pertama sebelah kanan dari persamaan (5) merupakan kombinasi linier dari fungsi skala $\varphi_{k}(n)$, dan merupakan kelompok sinyal untuk rentang frekuensi rendah, atau dikenal pula sebaagi komponen sinyal kasar (aproksimasi). Sementara suku kedua merupakan kombinasi linier dari fungsi wavelet $\psi_{j, k}(n)$, yang merupakan kelompok sinyal untuk rentang frekuensi tinggi, atau dikenal pula sebagai komponen sinyal halus (detil). Fungsi skala pada persamaan (5) diberikan oleh:

$$
\varphi_{j, k}(n)=2^{j / 2} \varphi\left(2^{j} n-k\right)
$$

Faktor $2^{j / 2}$ pada (4) dan (6) adalah untuk mempertahankan agar nilai norm dari masing-masing fungsi terbebas dari faktor skala $2^{j}$ yang diberikan. Sesuai dengan fungsinya pada (5), fungsi wavelet maupun fungsi skala pada (4) dan (6) dapat dinyatakan oleh model persamaan (weighted sum) berikut:

$$
\psi(n)=\sum_{k} h(k) \sqrt{2} \varphi(2 n-k)
$$

dan

$$
\varphi(n)=\sum_{k} g(k) \sqrt{2} \varphi(2 n-k)
$$

Dalam analisis wavelet diskrit (dyadic), untuk memenuhi tujuan dari persamaan (5), kedua fungsi bobot $h(k)$ dan $g(k)$ mempunyai hubungan satu dengan yang lain, dan diberikan oleh: 


$$
h(L-k-1)=(-1)^{n} g(k)
$$

dengan $L$ adalah panjang (orde) dari filter. Terlihat pada kedua analisis maupun sintesis wavelet bahwa pemilihan fungsi wavelet maupun fungsi skala adalah sangat penting. Terdapat banyak fungsi skala, atau dikenal pula sebagai mother wavelet function, yang tersedia dan telah dicoba untuk berbagai apalikasi. Satu sifat penting dari kedua fungsi tersebut adalah ortonormal. Setelah substitusi (4) dan (6), persamaan (5) dapat dituliskan sebagai:

$$
\hat{x}(n)=\sum_{k} c(j o, k) 2^{j o / 2} \varphi\left(2^{j o} n-k\right)+\sum_{k} \sum_{j=j o} d(j, k) 2^{j / 2} \psi\left(2^{j} n-k\right)
$$

Dengan indeks jo dapat berharga positip, negatip ataupun nol, yang selanjutnya akan menetapkan seberapa kasar komponen frekuensi rendah ikut serta dalam sintesis pada persamaan (10).

Obyektif pada analisis wavelet adalah mencari koefisien fungsi basis yang diberikan oleh persamaan (2). Untuk sintesis yang dinyatakan oleh persamaan (5) atau (10), fungsi basis yang dimaksud adalah fungsi skala $\varphi(n)$ dan fungsi wavelet $\psi(n)$. Untuk itu, dari sifat ortonormal kedua fungsi basis tersebut, dari persamaan (4), (6) dan (10) diperoleh berturut-turut:

$$
c(j, k)=\sum_{n} x(n) 2^{j / 2} \varphi\left(2^{j} n-k\right)
$$

dan

$$
d(j, k)=\sum_{n} x(n) 2^{j / 2} \psi\left(2^{j} n-k\right)
$$

masing-masing adalah koefisien fungsi skala dan koefisien fungsi wavelet. Kedua persamaan di atas adalah operasi konvolusi antara sinyal $x(n)$ dengan fungsi skala/wavelet. Sehingga, kedua koefisien yang dinyatakan oleh persamaan (11) dan (12) tersebut tidak lain adalah variabel diskrit fungsi waktu (sekuens data diskrit) yang diperoleh dari operasi konvolusi, atau filtering terhadap sinyal $x(n)$. Dengan demikian, $c(j, k)$ adalah sekuens diskrit sebagai produk dari filter halfband lowpass, sedangkan $d(j, k)$ adalah sekuens diskrit sebagai produk dari filter halfband high pass, masing-masing terhadap sinyal $x(n)$. Selanjutnya dari persamaan (8) dapat dituliskan:

$$
\begin{aligned}
\varphi\left(2^{j} n-k\right) & =\sum_{l} g(l) \sqrt{2} \varphi\left(2\left(2^{j} n-k\right)-l\right) \\
& =\sum_{m} g(m-2 k) \sqrt{2} \varphi\left(2^{j+1} n-m\right)
\end{aligned}
$$


Dan setelah substitusi ke dalam persamaan (11) diperoleh koefisien fungsi skala:

$$
\begin{aligned}
c(j, k) & =\sum_{m} g(m-2 k) \sum_{n} x(n) 2^{(j+1) / 2} \varphi\left(2^{j+1} n-k\right) \\
& =\sum_{m} g(m-2 k) c(j+1, m) \\
& =c(j+1, m) * g(-m)
\end{aligned}
$$

Dengan cara yang sama, dari (7) dan (12) dapat diperoleh koefisien fungsi wavelet:

$$
\begin{aligned}
d(j, k) & =\sum_{m} h(m-2 k) c(j+1, m) \\
& =c(j+1, m) * h(-m)
\end{aligned}
$$

Koefisien $h(k)$ dan $g(k)$ dapat diperoleh dari prototipe fungsi skala (mother wavelet) yang masing-masing adalah filter half band, dari kelas quadrature mirror filter (QMF), yang hubungannya satu dengan yang lain diberikan oleh persamaan (9). Pada penelitian ini telah dipilih fungsi symlet sebagai mother wavelet. Terlihat dari kedua persamaan (14) dan (15) bahwa analisis wavelet dapat diperoleh melalui filter halfband secara berjenjang hingga ke-level $j$ yang dikehendaki. Catat bahwa pada algoritma analisis wavelet diskrit yang dinyatakan pada (14) dan (15), $c\left(j_{\max }, k\right)$ tidak lain adalah $x(n)$. Dengan demikian kedua persamaan (14) dan (15) adalah realisasi dari proses dekomposisi sinyal $x(n)$ menjadi dua komponen, yaitu komponen dengan rentang frekuensi rendah dan komponen dengan rentang frekuensi tinggi. Dengan kedua persamaan di atas sinyal dapat didekomposisi hingga ke level skala pada rentang frekuensi yang lebih sempit, baik pada kelompok frekuensi tinggi maupun pada kelompok frekuensi rendah.

Dari konsep dekomposisi pada persamaan (14) dan (15), terlihat bahwa komponen-komponen sinyal $c(j, k)$ dan $d(j, k)$ keduanya berujung pada $c(j+1, m)$, dimana $c\left(j_{\max }, m\right)=x(m)$. Dengan demikian sintesis sinyal dapat diperoleh dengan menjumlahkan sinyal invers $c(j+1, m)$ untuk sepanjang waktu $m$ :

$$
\hat{x}(n)=\sum_{n} c(j+1, k) 2^{(j+1) / 2} \varphi\left(2^{j+1} k-n\right)
$$

Sementara, sinyal rekonstruksi (16) dapat pula diperoleh dengan menambahkan invers kedua komponen sinyal $c(j, k)$ dan $d(j, k)$ dari (11) dan (12): 


$$
\hat{x}(n)=\sum_{n} c(j, n) 2^{j / 2} \varphi\left(2^{j} k-n\right)+\sum_{n} d(j, n) 2^{j / 2} \psi\left(2^{j} k-n\right)
$$

Jika kemudian substitusi (7) dan (8) ke dalam (17) diperoleh:

$$
\begin{aligned}
\hat{x}(n)=\sum_{n} c(j, k) & \sum_{m} g(m) 2^{(j+1) / 2} \varphi\left(2^{j+1} k-2 n-m\right) \\
& +\sum_{n} d(j, k) \sum_{m} h(m) 2^{(j+1) / 2} \varphi\left(2^{j+1} k-2 n-m\right)
\end{aligned}
$$

Selanjutnya, persamakan persamaan (16) dan (18), kemudian perkalikan kedua sisi dengan $\varphi\left(2^{j+1} k-n^{\prime}\right)$, dan gunakan sifat ortonormal fungsi-fungsi skala, diperoleh algoritma rekonstruksi sinyal (sintesis) sebagai berikut:

$$
\begin{aligned}
c(j+1, k) & =\sum_{m} c(j, m) g(k-2 m)+\sum_{m} d(j, m) h(k-2 m) \\
& =c(j, m) * g(m)+d(j, m) * h(m)
\end{aligned}
$$

Persamaan (19) menunjukan bagaimana rekonstruksi (sintesis) sinyal $\hat{x}(n)$ dapat dilakukan secara bertahap, yang merupakan mirror dari operasi transformasi (analisis) wavelet yang dinyatakan oleh persamaan (14) dan (15) .

\subsection{Ekstraksi Gelombang EEG}

Konsep analisis yang dinyatakan oleh persamaan (14) dan (15) serta sintesis wavelet yang dinyatakan oleh persamaan (19) adalah merupakan dasar dari ekstraksi gelombang EEG yang dilakukan dalam penelitian ini. Proses transformasi wavelet dengan faktorisasi kedua komponen rentang frekuensi rendah dan tinggi oleh persamaan (14) dan (15), dikenal sebagai wavelet packet. Jika $x(n)$ adalah sinyal EEG, dengan transformasi wavelet yang dinyatakan oleh persamaan (14) dan (15), maka dapat diuraikan komponen-komponennya atas rentang frekuensi yang berjenjang. Dalam penelitian ini, untuk kasus sinyal EEG data eksperimen yang mempunyai frekuensi sampling 197.5 pixel/detik, hasil dekomposisi sampai dengan $j=5$, diperoleh hasil sebagaimana ditunjukan pada Gambar 4. Selanjutnya, berdasarkan informasi apriori pada rentang frekuensi gelombang teta, alfa, dan beta, maka dapat direkonstruksi sinyal EEG yang hanya mengandung ketiga gelombang di atas, yaitu dengan membuang komponen-komponen rentang frekuensi pada Gambar 4, kecuali rentang frekuensi dimana ketiga gelombang EEG di atas berada, yaitu rentang frekuensi $\quad(3.09-6.17 \mathrm{~Hz}), \quad(6.17-12.35 \mathrm{~Hz}), \quad(12.35-24.69 \mathrm{~Hz})$, dan $(24.69-$ $30.86 \mathrm{~Hz}$ ). Selanjutnya, dengan menggunakan persamaan (19), sinyal EEG terekstraksi dapat diperoleh. Dalam kasus ini sinyal terekstraksi yang diperoleh dari Gambar 4 hingga ke level $j=5$, adalah $\hat{x}(n)=c(5, n)$. 


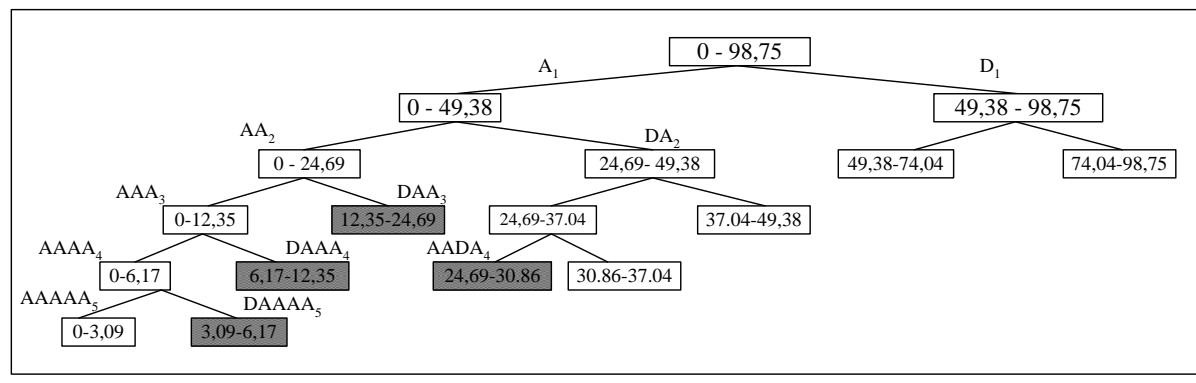

Gambar 4 Ekstraksi frekuensi dengan Wavelet Packets terhadap sinyal EEG dengan frekuensi sampling 197.5 pixels/second.

\section{Estimasi Kerapatan Spektral Daya}

Pada penelitian ini, sinyal terekstraksi dari transformasi wavelet yang diperoleh dari persamaan (18) di atas selanjutnya diperiksa kerapatan spektralnya, untuk mengetahui kehadiran gelombang EEG. Misalkan pada suatu saat $t=N T_{s}$ diberikan $N$ data $\{x(N): x(0), x(2), x(3), \ldots . ., x(N-1)\}$ dengan perioda sampling $T_{s}$. Kemudian $N$ data sinyal EEG $\{x(N)\}$ tersebut dibagi atas $K$ kelompok data $\{x(i, L)\}, i=1,2,3, \ldots, K$, masing-masing dengan panjang $L<N$, dimana $\{x(i, L)\}$ adalah kelompok ke $i$ dari data $\{x(N)\}$ sepanjang $L$ data. Maka spektral daya dari kelompok sinyal $\{x(i, L): x(i), x(i+1), x(i+2), \ldots, x(i+L-1)\}$ diberikan oleh:

$$
S_{x i}(\Omega)=\left|\sum_{l=0}^{L-1} x(i+l-m) e^{-j \Omega l}\right|^{2}, \quad \Omega=\frac{2 \pi}{N}
$$

Pada persamaan (20) di atas, $m \geq 1$ adalah faktor overlap satu kelompok sinyal terhadap kelompok sebelumnya/sesudahnya. Sehingga spektral daya dari $\{x(N)\}$ dengan metoda Welch diberikan oleh:

$$
S_{x}(\Omega)=\frac{1}{K} \sum_{i=1}^{K} S_{x i}(\Omega)
$$

Untuk memperbaiki fluktuasi pada sidelobe, yang dapat mengganggu resolusi spektral terestimasi, sebelumnya terhadap setiap kelompok sinyal dilakukan windowing:

$$
x_{w}(t)=x(t) w(t)
$$


dengan $\{w(n): w(0), w(1), w(2), \ldots . .$.$\} adalah sekuens fungsi window. Sehingga$ spektral daya yang diperoleh adalah:

$$
S_{x w}(\Omega)=\frac{1}{2 \pi N}|X(\Omega) * W(\Omega)|^{2}
$$

\section{$5 \quad$ Sistem Deteksi dan Identifikasi Gelombang}

Sistem deteksi dan identifikasi komponen-komponen gelombang sinyal EEG, dilakukan terhadap spektral daya atas sinyal terekstraksi pada tahapan transformasi wavelet. Pada penelitian ini, estimasi spektral dilakukan dengan persamaan (20), dengan window Bartlett lebar satu detik, dengan overlap 0,5 detik. Seperti telah dijelaskan pada Bagian 3, sistem deteksi dan identifikasi komponen-komponen gelombang sinyal EEG dilakukan terhadap spektral daya dari sinyal terekstraksi. Sesuai dengan informasi apriori pada penelitian terdahulu ${ }^{[12,13]}$, bahwa kondisi pikiran ditandai oleh kemunculan gelombang tertentu pada sinyal EEG. Kondisi rileks ditandai/diidentifikasi dengan dominasi energi gelombang alfa $(8-13 \mathrm{~Hz})$, kondisi berpikir diidentifikasi dengan energi gelombang beta (14-30 Hz) yang dominan, sedangkan kondisi mengantuk/stres emosional ditandai oleh kehadiran energi gelombang teta (4-7 $\mathrm{Hz}$ ). Mengingat naracoba dalam keadaan normal dan sadar, kecil kemungkinan gelombang delta akan muncul. Oleh karena itu, pada penelitian ini dengan sengaja tidak dilakukan deteksi dan identifikasi terhadap komponen gelombang delta. Untuk menjelaskan lebih baik proses deteksi dan identifikasi gelombang EEG, tinjau 3 komponen spektral daya hasil ekstraksi wavelet $F(\omega)$ dari tiap gelombang EEG, yaitu gelombang alfa $(\alpha)$, gelombang beta $(\beta)$ dan gelombang teta $(\theta)$, seperti yang diperlihatkan pada Gambar 5 .

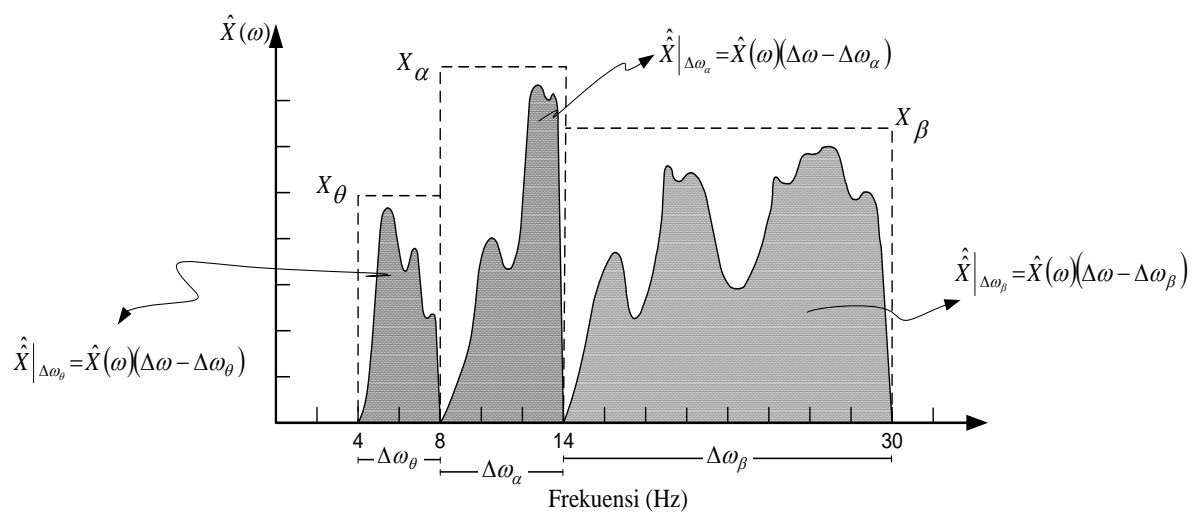

Gambar 5 Spektral daya tiap gelombang hasil ekstraksi dalam bingkai masingmasing 
Berdasarkan spektral daya pada Gambar 5 tersebut, selanjutnya dapat dituliskan model spektral sinyal EEG hasil ekstraksi dengan transformasi wavelet, yang mengandung ketiga komponen spektral gelombang EEG sebagai berikut:

$$
\hat{X}(\omega)=\sum_{i=\theta, \alpha, \beta} X(\omega) \delta\left(\omega-\Delta \omega_{i}\right)
$$

dengan $X(\omega)$ adalah spektral daya sinyal EEG sebelum ekstraksi, dan

$$
\begin{array}{rll}
\delta\left(\omega-\Delta \omega_{i}\right)=1, & \omega=\Delta \omega_{i} \quad \text { dimana } & 8 \leq \Delta \omega_{\alpha} \leq 14 \\
=0, & \omega \neq \Delta \omega_{i} & 14 \leq \Delta \omega_{\beta} \leq 30
\end{array}
$$

Selanjutnya, kehadiran satu atau lebih komponen gelombang EEG dapat diperiksa dari energi spektral yang diberikan oleh persamaan (24) terhadap besaran threshold yang ditetapkan, $\eta$, atau:

$$
\hat{\Pi}(\omega) \geq \eta
$$

Kemudian, untuk identifikasi gelombang EEG dapat diberikan model kehadiran masing-masing gelombang EEG sebagai berikut:

$$
\hat{\hat{X}}_{i}(\omega)=\hat{\hat{X}}(\omega) \delta\left(\omega-\Delta \omega_{i}\right), \quad i=\theta, \alpha, \beta
$$

dengan $\hat{\hat{X}}(\omega)$ adalah hasil estimasi dari $\hat{X}(\omega)$ menggunakan persamaan (23). Selanjutnya, kehadiran suatu jenis gelombang EEG diidentifikasi dari detektor berikut:

$$
\gamma_{i}=\frac{\hat{\Pi}\left(\omega_{i}\right)}{\Pi_{i}} \times 100 \% \geq \eta_{i}, \quad i=\theta, \alpha, \beta
$$

Dimana $\hat{\Pi}\left(\omega_{i}\right)$ adalah luas spektral (27), sedangkan $\Pi_{i}$ adalah luas dari band frekuensi gelombang EEG yang bersangkutan yang diberikan oleh (lihat Gambar 5):

$$
\Pi_{i}=X_{i} \times \Delta \omega_{i}, \quad i=\theta, \alpha, \beta
$$

dengan $X_{i}$ adalah tinggi nominal dari spektral gelombang EEG yang bersangkutan. Selanjutnya diperkenalkan angka kehadiran $\gamma_{h}(i)$ sebagai berikut:

$$
\gamma_{h}(i)=\frac{\gamma_{e}(i)-\gamma_{o}(i)}{\gamma_{o}(i)}, \quad i=\theta, \alpha, \beta
$$


dimana $\gamma_{e}(i)$ adalah prosen kehadiran gelombang $i$ sesudah rangsangan suara diberikan $\gamma_{o}(i)$ adalah prosen kehadiran gelombang $i$ sesudah rangsangan suara diberikan. Jika $\gamma_{h}(i)$ mempunyai harga lebih besar dari threshold (10\%), maka dideteksi sebagai kemunculan gelombang yang bersangkutan. Sebaliknya, jika $\gamma_{h}(i)$ mempunyai harga lebih kecil dari threshold (-10\%), maka dideteksi sebagai hilangnya gelombang yang bersangkutan.

\subsection{Sistem Identifikasi Gelombang Alfa, Beta,Teta}

Skema sistem identifikasi gelombang dilukiskan pada Gambar 6. Spektral sinyal terekstraksi selanjutnya diidentifikasi luasnya terhadap angka threshold luas nominal untuk masing-masing gelombang $\delta\left(\omega-\Delta \omega_{i}\right)$. Untuk itu masingmasing dibandingkan terhadap $\eta_{\mathrm{i}}$. Kemudian sistem identifikasi dilakukan sebagai berikut:

a. Kemunculan gelombang tertentu

Kemunculan gelombang tertentu diidentifikasi dari spektral daya pada daerah masing-masing gelombang yang dibandingkan antara kondisi sebelum dan sesudah rangsangan suara diberikan.

b. Keseimbangan kanal simetrik

Dengan pemberian rangsangan dideteksi keseimbangan kanal kiri-kanan yang simetrik, karena menurut penelitian terdahulu, kondisi rileks ditandai dengan semakin seimbangnya gelombang antara dua kanal yang simetrik kiri-kanan. $^{[7-12,19]}$

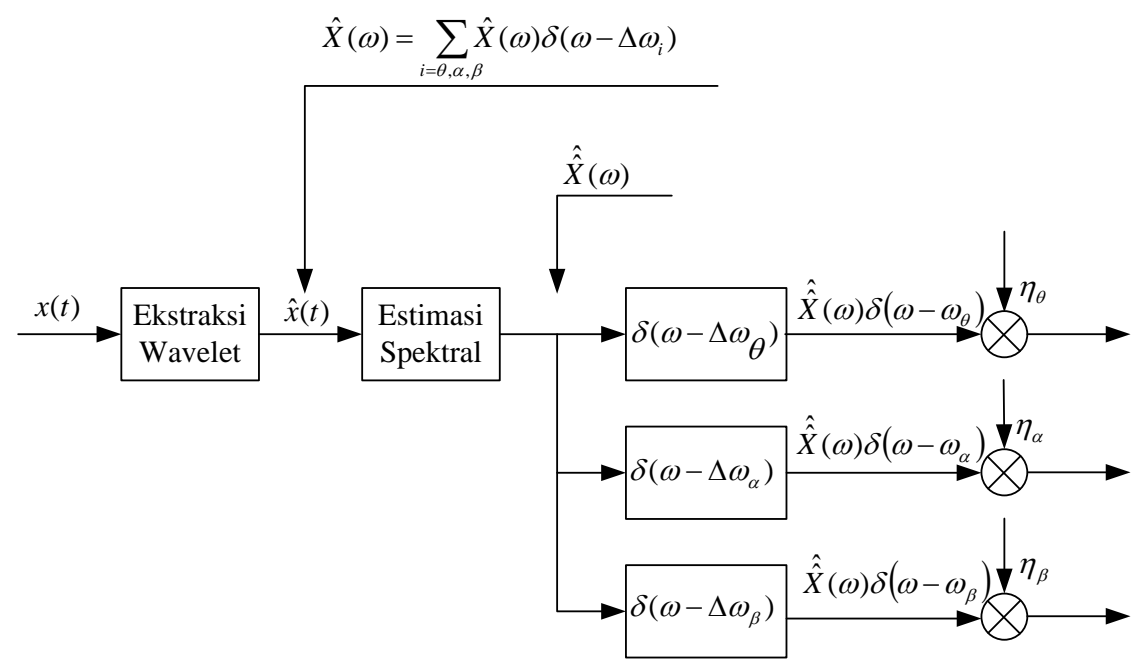

Gambar 6 Sistem identifikasi gelombang alfa, beta, dan teta. 
c. Distribusi Gelombang pada Kanal-kanal Terhadap Rangsangan Suara.

Setiap rangsangan suara diamati distribusi gelombang (alfa, beta, dan teta) terhadap kanal-kanal pengukuran.

\section{Hasil Pengujian}

Sebagaimana telah disebutkan di depan, pada penelitian ini digunakan wavelet packets yang menghasilkan ekstraksi komponen frekuensi yang meliputi rentang 3,09-30,86 Hz. Selanjutnya, terhadap sinyal terekstraksi dilakukan analisis spektral daya, seperti ditunjukkan pada Gambar 7a. Terlihat pada gambar bahwa perubahan pola spektral daya terjadi antara waktu 0.5-2.5 menit, saat sumber suara diperdengarkan dibandingkan dengan kondisi diam antara menit ke-0 sampai menit ke-0.5. Secara umum masing-masing spektral cukup konsisten, yang berarti mendekati kondisi stasioner.

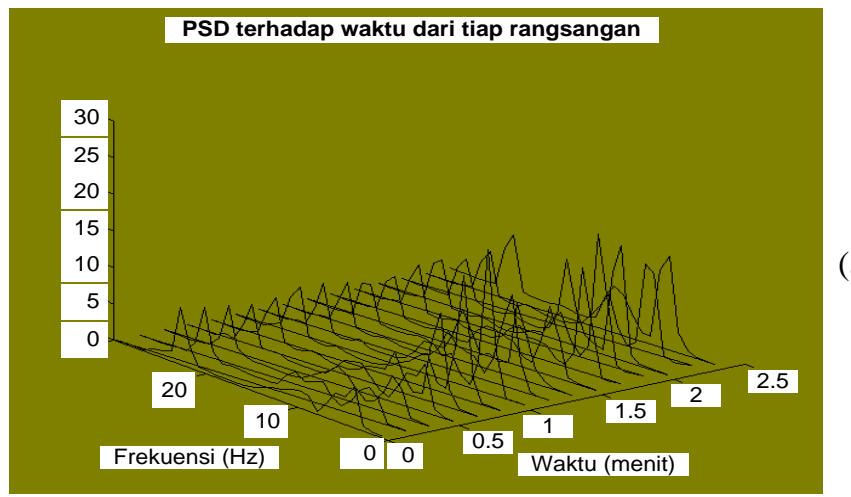

(a)

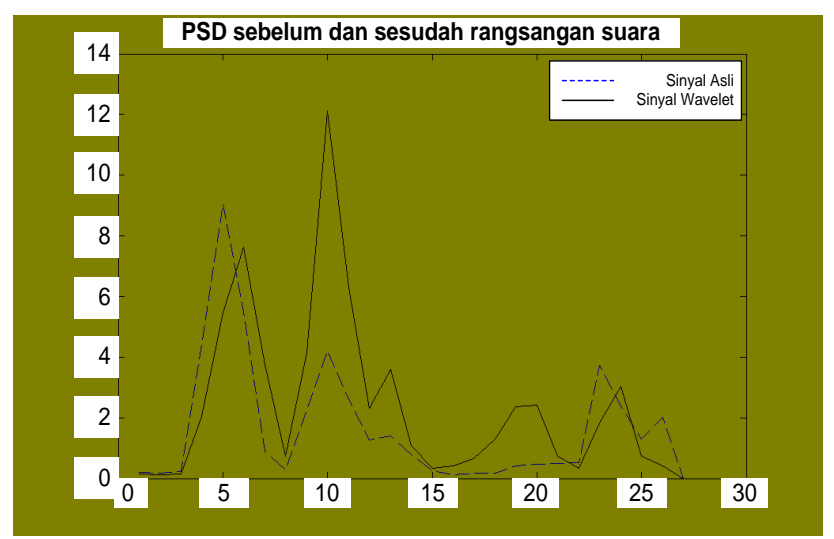

(b)

Gambar 7 PSD dari sinyal wavelet nara coba 1, trial 1 (suara no.1, Tabel 2) terhadap waktu. 
Sementara itu, rangsangan suara memberikan pengaruh terhadap kemunculan ataupun pengurangan gelombang tertentu, seperti diperlihatkan pada Gambar 7b. Pada gambar tersebut ditunjukan bahwa akibat rangsangan suara, daya gelombang alfa meningkat sementara daya gelombang beta dan teta menurun. Namun tidak semua kasus (terdapat 20 kasus: 5 nara coba $\mathrm{x} 4$ perulangan) memperlihatkan hal tersebut.

Pada penelitian ini, hasil sistem deteksi dan identifikasi dibagi atas 3 bagian, yaitu: peningkatan gelombang akibat rangsangan suara, analisis sinkronisasi, dan analisis dominasi gelombang.

a. Peningkatan gelombang.

Dari 20 kasus, dideteksi banyaknya kenaikan/penurunan gelombanggelombang EEG terhadap rangsangan suara yang diberikan. Hasil deteksi kemunculan gelombang dari 20 kasus diperlihatkan pada Tabel 2 yang merupakan rata-rata dari seluruh kanal.

Table 2 Kemunculan gelombang terhadap rangsangan suara rata-rata.

\begin{tabular}{|c|c|c|c|l|c|c|c|}
\hline \multirow{2}{*}{ No. } & \multirow{2}{*}{ Instrumen } & \multirow{2}{*}{ Warna } & \multirow{2}{*}{ Jenis } & \multirow{2}{*}{ Tempo } & \multicolumn{3}{|c|}{ Kenaikan (\%) } \\
\cline { 6 - 8 } & & & & Alfa & Beta & Teta \\
\hline 1. & Biola, cello & minor & lunak & lambat-sedang & 89 & -39 & -25 \\
\hline 2. & Piano & mayor & tajam & sedang & 48 & -41 & -60 \\
\hline 3. & Piano & minor & agak tajam & lambat & 73 & -44 & -53 \\
\hline 4. & Biola, cello & minor & agak lunak & lambat sedang & 84 & -53 & -55 \\
\hline 5. & Piano & minor & agak lunak & sedang & 63 & -68 & -65 \\
\hline 6. & Piano & minor & lunak, datar & Lambat & 50 & -46 & -61 \\
\hline 7. & Piano, biola, & minor & agak lunak & lambat sedang & 70 & -77 & -39 \\
\hline 8. & Piano & minor & $\begin{array}{c}\text { agak lunak, } \\
\text { sedikit tajam }\end{array}$ & Lambat & 96 & -21 & -56 \\
\hline 9. & Piano elektrik & mayor & tajam & Sedang & 90 & -49 & -57 \\
\hline 10. & Piano & minor & agak lunak & Lambat & 66 & -46 & -65 \\
\hline 11. & $\begin{array}{c}\text { Air terjun } \\
\text { alami }\end{array}$ & minor & $\begin{array}{c}\text { sangat } \\
\text { lunak, datar }\end{array}$ & Lambat & 71 & -41 & -74 \\
\hline 12. & $\begin{array}{c}\text { Suara burung } \\
\text { di hutan }\end{array}$ & mayor & agak tajam & Sedang & 94 & -54 & -66 \\
\hline
\end{tabular}

Tanda (+) berarti energi gelombang tersebut naik, sementara (-) menurun. Terlihat dari Tabel 2, dari 12 jenis rangsangan suara yang digunakan dalam penelitian ini, dari 320 kasus naracoba, menunjukan 48-96\% gelombang alfa meningkat signifikan (lebih dari 10\%), sedangkan terdapat 21-77\% gelombang beta dan $25-74 \%$ untuk gelombang teta yang menurun. Jika dianalisis pada tiap rangsangan suara, peningkatan gelombang alfa terjadi paling besar (lebih dari 80\% kasus) pada musik No. 1, 4, 8, 9, dan 12. 
Dengan demikian dapat ditarik kesimpulan bahwa dengan rangsangan suara yang digunakan pada penelitian ini, kondisi nara coba menjadi lebih rileks. Hal ini ditandai dengan peningkatan gelombang alfa, dan penurunan gelombang beta dan teta.

b. Analisis Keseimbangan dari kanal simetri

Setiap grafik sinyal EEG dinyatakan sebagai pasangan simetri kanan-kiri. Kondisi simetri atas kanal gelombang listrik pada otak merupakan salah satu pengamatan yang biasa digunakan dokter dalam analisis sinyal EEG. Pada dasarnya gelombang listrik di otak kiri dan kanan yang simetrik adalah berbeda. Namun untuk kondisi tenang/rileks, gelombang tersebut cenderung simetrik, seperti dinyatakan dalam penelitian lalu ${ }^{[19]}$. Oleh karena itu pada penelitian ini dianalisis keadaan keseimbangan akibat rangsangan suara dari kanal yang simetrik.

Hasil penelitian ini menunjukkan bahwa untuk gelombang alfa 58-86\% menuju seimbang, sementara secara keseluruhan untuk gelombang alfa, beta, dan teta memberikan keseimbangan $63-78 \%$ setelah diperdengarkan rangsangan suara. Hal ini menginformasikan pula kondisi rileks pada naracoba. Untuk lebih jelas, dapat dilihat Gambar 8, yang merupakan grafik penurunan ketidakseimbangan dari 8 pasang kanal yang simetrik, yang secara keseluruhan hampir sama setiap kanalnya. Sementara dari Gambar 9 ditunjukkan bahwa keseimbangan gelombang paling besar terjadi pada daerah depan dan tengah, yang merupakan pusat pikiran seseorang. Reprentasi kesimetrian gelombang pada kanal simetrik akibat rangsangan suara, dapat dilihat pula dari Gambar 9, yang merupakan contoh kasus dari 6 rangsangan suara.

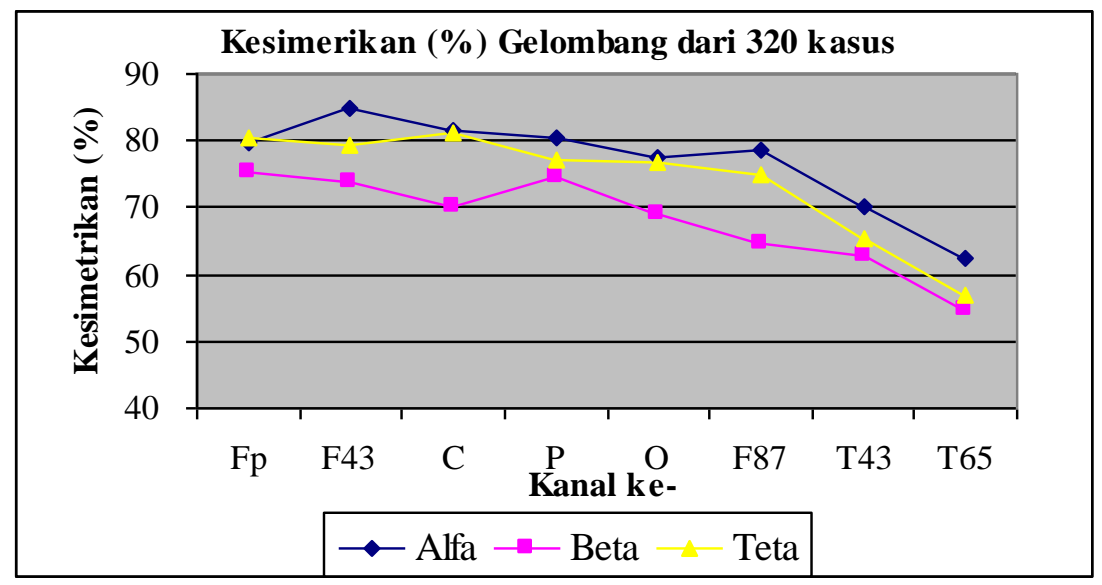

Gambar 8 Pengaruh sinkronisasi terhadap rangsangan suara. 

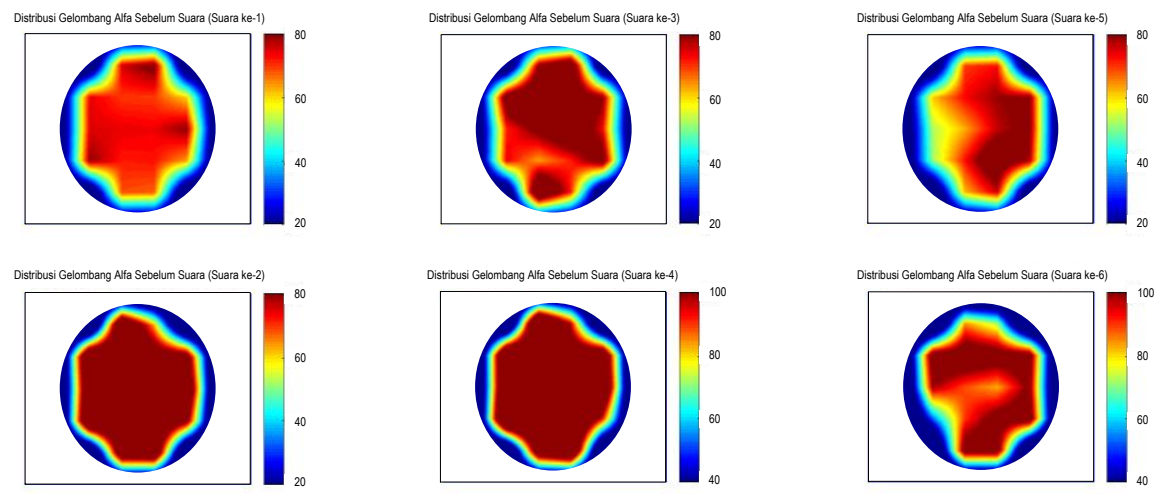

Gambar 9 Distribusi pengaruh keseimbangan terhadap rangsangan suara.

c. Dominasi gelombang

Gelombang yang muncul dalam suatu kondisi tanpa rangsangan suara dideteksi dominasinya, yang kemudian dibandingkan dominasinya setelah rangsangan suara diperdengarkan. Diperoleh, sebelum pemberian rangsangan suara, terdapat $57 \%$ kondisi yang dominan pada gelombang alfa, sementara gelombang beta dominan $40 \%$, dan gelombang teta dominan $17 \%$ dari kasus yang diamati. Akibat pemberian rangsangan suara, gelombang alfa meningkat, yang dominan meliputi $90 \%$ kasus, sementara gelombang beta menurun, yang dominan hanya $7 \%$ kasus. Hasil ini sejalan dengan peningkatan gelombang alfa dan penurunan gelombang lainnya.

Table 3 Pembobotan 12 sumber suara.

\begin{tabular}{|c|c|c|c|c|c|}
\hline No. & Instrumen & Warna & Jenis & Tempo & Nilai \\
\hline 1. & Biola, cello & minor & lunak & lambat-sedang & 6 \\
\hline 2. & Piano & mayor & tajam & sedang & 6 \\
\hline 3. & Piano & minor & agak tajam & lambat & 7 \\
\hline 4. & Biola, cello & minor & agak lunak & lambat sedang & 8 \\
\hline 5. & Piano & minor & agak lunak & sedang & 8 \\
\hline 6. & Piano & minor & lunak, datar & lambat & 6 \\
\hline 7. & Piano, biola, & minor & agak lunak & lambat sedang & 8 \\
\hline 8. & Piano & minor & $\begin{array}{c}\text { agak lunak, } \\
\text { sedikit tajam }\end{array}$ & lambat & 6 \\
\hline 9. & Piano elektrik & mayor & tajam & sedang & 5 \\
\hline 10. & Piano & minor & agak lunak & lambat & 6 \\
\hline 11. & $\begin{array}{c}\text { Air terjun } \\
\text { alami }\end{array}$ & minor & $\begin{array}{c}\text { sangat lunak, } \\
\text { datar }\end{array}$ & lambat & 8 \\
\hline 12. & Suara burung & mayor & agak tajam & sedang & 6 \\
\hline
\end{tabular}


Hasil evaluasi 12 sumber suara yang digunakan dalam penelitian ini berdasarkan urutan pengaruhnya yang memberikan kondisi rileks, memberikan hasil seperti yang dilihat pada Tabel 3. Pembobotan pada Tabel 3 dilakukan berdasarkan peringkat dari tiga bagian sistem deteksi dan identifikasi yang telah dijelaskan di atas. Penilaian tertinggi diberikan pada suara yang meningkatkan gelombang alfa, penurungan gelombang beta dan teta, peningkatan dominasi gelombang, dan peningkatan keseimbangan. Terlihat pada Tabel 3. pengaruh rangsangan suara satu dengan lain tak terlalu signifikan. Dari 12 rangsangan suara yang digunakan dalam penelitian, hasil terbaik memberikan kondisi rileks terjadi jika diberikan rangsangan suara No. 4 dan 5 (musik klasik), No. 7 (musik lembut) dan No. 11 (musik alami). Sementara itu, preferensi nara coba hasil kuisioner tidak terlalu berbeda.

d. Distribusi Gelombang terhadap Rangsangan Suara

Sumber suara yang digunakan secara umum memberikan peningkatan gelombang alfa atau kondisi nara coba ke arah rileks. Jika diplot terhadap posisi kanal, gelombang alfa dari kanal-kanal pengukuran tampak pada Gambar 10.

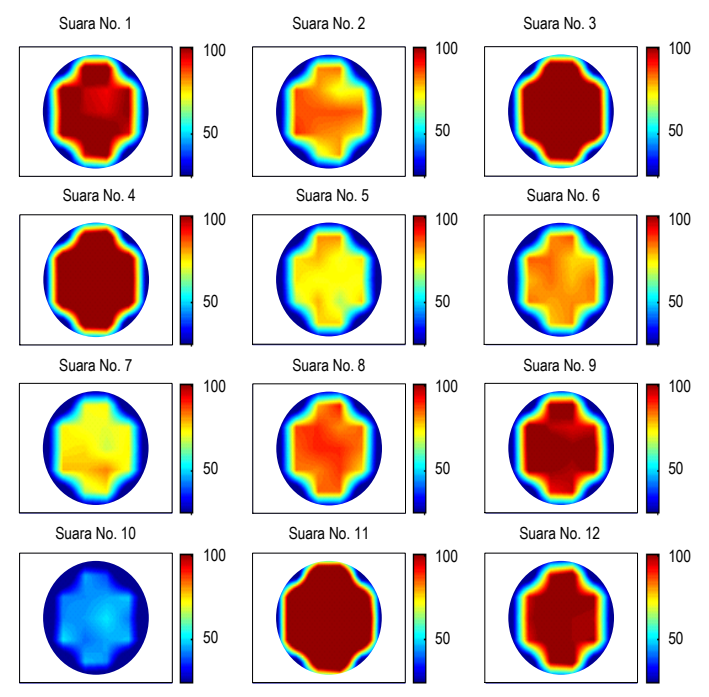

Gambar 10 Distribusi gelombang alfa pada nara coba 1 dengan 12 suara

Gambar 10 menunjukkan bahwa peningkatan gelombang alfa paling besar pada suatu nara coba terdapat pada suara No. 3,4,11, dan 12. Hasil ini dikaitkan dengan bobot evaluasi rangsangan suara pada Tabel 3 . 


\section{$7 \quad$ Kesimpulan dan Penutup}

Pada penelitian ini telah ditunjukan kombinasi ekstraksi sinyal dengan wavelet packets dengan spektral daya untuk mendeteksi dan mengidentifikasi kehadiran gelombang-gelombang di otak untuk mengklasifikasi kondisi pikiran seseorang. Selanjutnya, hasil penelitian ini memperlihatkan pula bahwa rangsangan suara yang digunakan dalam penelitian mampu memberikan peningkatan 48-96\% gelombang alfa yang signifikan (lebih dari 10\%), sedangkanterdapat 21-77\% untuk gelombang beta dan $25-74 \%$ untuk gelombang teta yang menurun signifikan dari keseluruhan kasus yang ada.

Dari penelitian ini telah diketahui bahwa rangsangan suara telah memberikan keseimbangan gelombang pada kanal yang simetri. Pada gelombang alfa memberikan keseimbangan $58-86 \%$, sementara secara keseluruhan untuk gelombang alfa, beta, dan teta memberikan keseimbangan 63-78\%. Dari penelitian ini pula dapat diketahui bahwa rangsangan suara yang digunakan pada penelitian ini secara umum memungkinkan dapat digunakan untuk terapi emosional dan kejiwaan. Hal ini dapat disimpulkan, mengingat bahwa rangsangan suara telah dapat memberikan kondisi rileks pada nara coba, yang ditandai oleh peningkatan gelombang alfa dan penurunan gelombang lainnya, serta keseimbangan pada gelombang.

\section{Daftar Pustaka}

1. Anderson, C. W. \& Sijercic, Z., Classification of EEG Signals from Four Subjects During Five Mental Tasks, Proceeding of the Conference on Engineering Applications in Neural Networks '96, Turku - Finland, pp. 407 - 414 (1996).

2. $\quad$ Culpepper, J., Discriminating Mental States Using EEG Represented by Power Spectral Density, Department of Computer Science, Harvey Mudd College Claremont.

3. D'Attellis, C. E., Isaacson, S. I. \& Sirne, R. O., Detection of epileptic events in electroencephalograms using wavelet analysis, Annals of Biomedical Engineering, 25:286-293 (1997).

4. Di Xiao, Hao Yang, Shouchang, Extraction of $40 \mathrm{~Hz}$ EEG Bursts for Chaos Analysis of Brain Function, IEEE Engineering in Medicine \& Biology Magazine, vol. 16, pp 27-32 (1997).

5. Djamal, E. C. \& Muchtadi, F. I., Application Wavelet Transformation for Modeling Electroencephalogram Signal, Proceeding of IndonesiaGerman Conference, Bandung (July 2001).

6. Djamal, E. C. \& Tjokronegoro, H. A., Deteksi dan Identifikasi Sinyal EEG terhadap Rangsangan Suara dengan Analisis Spektral dan Transformasi Wavelet, Prosiding Seminar SIK'2003, Bandung (Juli 2003). 
7. Djamal, E. C. \& Tjokronegoro, H. A., Klasifikasi Kondisi Pikiran terhadap Rangsangan Suara dengan Analisis Spektral Daya, Prosiding Seminar SIK'2003, Bandung (Juli 2003).

8. Djamal, E. C. \& Tjokronegoro, H. A., Klasifikasi Sinyal EEG dua Kondisi Pikiran Menggunakan Analisis Spektral Daya dari Koefisien Wavelet, Majalah Instrumentasi (Juni 2003).

9. Djamal, E. C. \& Tjokronegoro, H. A., Deteksi dan Identifikasi Gelombang-Gelombang di otak untuk Klasifikasi Rangsangan Suara, Instrumed 2003, Surabaya (Okt 2003).

10. Djamal, E. C., Harijono Tjokronegoro, Soegijanto, Klasifikasi Sinyal EEG terhadap Kondisi Pikiran dengan Spektral Daya Wavelet, Jurnal IPTEK ITS, ed. Februari 2005 (Februari 2005).

11. Djamal, E. C. \& Harijono Tjokronegoro, Analisis Spektral Daya dari Transformasi Wavelet Asimetri Sinyal EEG Untuk Deteksi dan Identifikasi Dua Kondisi Pikiran, Jurnal Teknologi FT-UI, ed. 4 (Desember 2004).

12. Jin, S. H., Jeong, J., Jeong, D.-G., Kim, D.-J. \& Kim, S. Y., Nonlinear dynamics of the EEG separated by independent component analysis after sound and light stimulation, Biological Cybernetics, 86:395-401 (2002).

13. Kim, J.H., Min Cheol Whang \& Jeung Hwan Kim, The Classification of Visual Stimulus Using Wavelet Transform from EEG Signals, XIII ${ }^{\text {th }}$ Annual International Occupational Ergonomics and Safety Conference, Michigan (1998).

14. Kreiszyk, R., Neural Network with Wavelet Preprocessing in EEG Artifact Recognition, Warsaw (1999).

15. Muchtadi, F. I., Kusumandari, D.W., Analisis Sinyal EEG Teknik Bipolar dengan Photostimulan, Presentasi PPIKIM, Serpong (1999).

16. Oohashi, T., Nishina, E., Kawai, N., High Frequency Sound Above the Audible Range Affects Brain Electric Activity and Sound Perception, Presentation at the 91st Convention an Audio Engineering Society, New York (1991).

17. Oropesa, E., Cycon, H. L. \& Marc Jobert, Sleep Stage Classification using Wavelet Transform and Neural Network, Technical report 8 ICSI California (1999).

18. Sartorettoa, F., Ermani, M., Automatic detection of epilepticform activity by single-level wavelet analysis, Clinical Neurophysiology 110 (1999) 239-249.

19. Štolc S., Krakovská, A., Teplan, M., Audiovisual Stimulation of Human Brain Linear and Nonlinear Measures, MEASUREMENT SCIENCE REVIEW, Volume 3, Section 2 (2003).

20. Suprijanto, Muchtadi, F. \& Djamal, E. C., Klasifikasi Sinyal EEG Menggunakan Jaringan Saraf Tiruan Berarsitektur Umpan Maju, Presentasi PPIKIM, Serpong (1999). 
21. Xiaoli Li, Wavelet Spectral Entropy for Indication of Epileptic Seizure in Extracranial EEG, Dept. of Automation and Computer-Aided Engineering, The Chinese University of Hong Kong, Hong Kong (2002).

22. Wojdyllo, P., Wavelets, Rough sets and Artificial Neural Networks in EEG Analysis, Clinical Neurophysiology (1998).

23. _ Music and the Brain, The Amen Clinics Inc., A Medical Corporation (2003).

$24 . \quad$ Konsultasi pribadi Dr. dr. Oerip Santoso dan Bony Facius Harsono (komisi musik liturgi KWI), tentang karakteristik musik (2005). 